\title{
The Methodology of Quality Matrix in Manufacturing Quality Process Improvement
}

Milan Dian

Faculty of Technology and Production Management, University of J. E. Purkyne in Usti nad Labem, Na Okraji 1000,400 96 Usti nad Labem, Czech Republic.dian@fvtm.ujep.cz

In each industrial entrepreneur organization around the globe a three dimensional objective well known under the abbreviation QCD (Quality, Costs, and Delivery) is examined, pursued, and evaluated on daily basis. The nowadays crucial philosophy pertaining to process improvement in terms of quality assurance and significant cost reduction is that: "The quality must be manufactured and not controlled up". In order to be successful on the market place it is necessary to orchestrate, implement and carry out an advanced production quality assurance system with appropriate tools of course accompanying with previously precisely organized prototype and preserial stages of production. The article deals with a proposal of adequate methodology and the experimental implementation of quality matrix into manufacturing process assurance in order to improve a quality level and the whole QCD.

Keywords: process improvement, quality assurance, quality tools, quality matrix

\section{References}

[1] SUMMERS, D. (1997). Quality. Prentice-Hall Inc. NJ, USA. ISBN 0-02-418566-3

[2] ISO/TS (2009). Systémy managementu kvality - Zvláštní požadavky na používání ISO 9001:2008 v organizacích zajištujících sériovou výrobu náhradních díli̊ v automobilovém průmyslu. CSJ, Praha. ISBN 978-80-02-02186-6

[3] SEDDON, J. (2008). Bez př́kazů a ř́izení. CSJ, Praha. ISBN 978-80-02-01988-6.

[4] TÖPFER, A. (2008). Six Sigma. Computer Press, Brno. ISBN 978-80-251-1766-8

[5] KUJAWA, A., LEGUTKO, S. (2012) Productivity Investigation within the ERP System. Manufacturing Technology, Vol 12, No 12, pp 34-38.

[6] BORKOWSKI, S., KNOP, K., MIELCZAREK, K. (2012) The Use of Six Sigma Indicators for Measurement Process Quality of Product's Conformity Assessment in the Alternative Control. In: Quality Control as Process Improvement Factor. Czestochowa, pp 116-131. ISBN 978-934225-3-1

[7] VEBER, J. (2008). Management kvality, environmentu a bezpečnosti práce. Management Press, Praha. ISBN 97880-7261-210-9

[8] CIERNA H., TAVODOVA M. (2013) Using the Design of Experiment Method to Evaluate Quality of Cuts after Cutting Aluminum Alloy by AWJ. Manufacturing Technology, Vol 13, No 3, pp 302-307.

[9] DIAN, M. (2011). Některá rizika současné praxe při zajišt’ování kvality výrobků. In: Rizika podnikových procesů.

[10] Univerzita J. E. Purkyně, Fakulta výrobních technologií a managementu. Ústí nad Labem. ISBN 978-80-7414371-7.

[11] DIAN, M. (2012). Contemporary Problems with Manufactured Product and Tools for Problem Solving. In: Toyotarity, Materials and Special Purpose Products Quality. University of Maribor, pp 100-114. ISBN 978-961-656261-4.

[12] STASIAK-BETLEJEWSKA, R. (2012) Value engineering as the way of quality problems solving in the steel construction management. Manufacturing Technology, Vol 12, No 13, pp 242-247.

[13] HORVATH, G. (2012). Rizika vybraných podnikových procesů. Univerzita J. E. Purkyně, Fakulta výrobních technologií a managementu. Ústí nad Labem. ISBN 978-80-7414-522-3. 